\title{
Adsorption Characteristics of Stone-Bentonite Mixtures towards Zn: Equilibrium and Kinetic Tests
}

\author{
Sifa $\mathrm{Xu}^{1}$, Yajun $\mathrm{Fu}^{1}$, Weiwei Wei ${ }^{2}$, Cuifeng $\mathrm{Li}^{3}{ }^{3}$, Mengdan Bian ${ }^{4}$ and Zhe Wang ${ }^{1, *}$ \\ 1 Institute of Geotechnical Engineering, Zhejiang University of Technology, Hangzhou 310023, China; \\ xusifa@zjut.edu.cn (S.X.); yajunfu2021@163.com (Y.F.) \\ 2 Zhongtian Construction Group Co., LTD., Dongyang 322100, China; weiweiweizt@163.com \\ 3 State Grid Ningbo Power Supply Company, Ningbo 315000, China; licuifeng93@163.com \\ 4 Library, Zhejiang University of Technology, Hangzhou 310014, China; mengdanbian@163.com \\ * Correspondence: wangzsd@163.com or wangzsd@zjut.edu.cn; Tel.: +86-1396-8110-665
}

check for

updates

Citation: Xu, S.; Fu, Y.; Wei, W.; Li, C.; Bian, M.; Wang, Z. Adsorption Characteristics of Stone-Bentonite Mixtures towards Zn: Equilibrium and Kinetic Tests. Processes 2021, 9, 619. https://doi.org/10.3390/ pr9040619

Received: 10 March 2021

Accepted: 26 March 2021

Published: 1 April 202

Publisher's Note: MDPI stays neutral with regard to jurisdictional claims in published maps and institutional affiliations.

Copyright: (c) 2021 by the authors. Licensee MDPI, Basel, Switzerland This article is an open access article distributed under the terms and conditions of the Creative Commons Attribution (CC BY) license (https:// creativecommons.org/licenses/by/ $4.0 /)$

\begin{abstract}
In the treatment of industrial polluted sites and the construction of landfill sites, antipollution barriers are usually used to prevent the diffusion of pollutants. In this paper, the adsorption characteristics of $\mathrm{Zn}$ ions by the rock-bentonite anti-pollution barrier were observed by means of static equilibrium and dynamic adsorption tests. The experimental results showed that the adsorption of $\mathrm{Zn}$ by stone chips-bentonite was close to the nonlinear Freundlich and Langmuir models. When the concentration of $\mathrm{Zn}$ ion is constant, the adsorption capacity increases with the increase in temperature. At a certain temperature, the adsorption removal rate decreases with the increase in concentration. Further study found that the adsorption of $\mathrm{Zn}$ from mixed soil was mainly an ion exchange process, and the adsorption mode of $\mathrm{Zn}$ from mixed soil was controlled by both intra-particle diffusion and membrane diffusion. Zeta potential, X-ray diffraction (XRD) and The Fourier Transform Infrared spectroscopy (FTIR) showed that with the increase in concentration, the mixed soil adsorbed more metal ions, and the thickness of the double electric layer decreased. Moreover, the adsorption of $\mathrm{Zn}^{2+}$ by bentonite was mainly interlayer adsorption and ion exchange. As an anti-pollution barrier material, the mixed soil of stone chips -bentonite can prevent the diffusion of pollutants, which has certain reference significance for engineering construction.
\end{abstract}

Keywords: stone-bentonite; heavy metal of Zn; equilibrium isothermal adsorption; dynamic isothermal adsorption; zeta potential

\section{Introduction}

With the advancement of urbanization, the production of domestic waste increases, which brings great problems to waste treatment [1]. In addition, the removal of chemical and metallurgical enterprises from the city center has left a large area of polluted sites, posing a serious threat to the surrounding environment [2-4]. Anti-fouling barriers are widely used in the construction of landfill sites and the treatment of contaminated sites to prevent leachate leakage and pollutant diffusion [5-7].

Many scholars have conducted research on the adsorption characteristics of heavy metals through adsorption tests. When studying the effects of reaction time and initial concentration of heavy metals on the adsorption effect, Chen et al. [8] conducted static equilibrium and dynamic adsorption tests on $\mathrm{Pb}$ by silt-loess mixed soil, and found that the adsorption amount of $\mathrm{Pb}$ by mixture increased with the increase in initial concentration and reaction time, and eventually tended to be saturated. The findings of Liu et al. [9] were consistent with those of Chen. In the experimental study on the adsorption of heavy metals $\mathrm{Pb}$ and $\mathrm{Zn}$ by sand-bentonite vertical barrier materials, it was found that the adsorption capacity of sand-bentonite for $\mathrm{Pb}$ and $\mathrm{Zn}$ increased with the increase in solute concentration. Shi et al. [10] suggested that bentonite has a good adsorption and removal effect on heavy metal ions $\mathrm{Zn}$, and the adsorption rate was fast. When it comes to 
the influence of temperature and initial concentration of solution on the adsorption effect, Wang et al. [11] found that the adsorption capacity of biochar on heavy metal Zn gradually increases with the increase in temperature and initial concentration. Dogan et al. [12] found that the adsorption effect of sepiolite on heavy metals was enhanced with the increase in reaction temperature. When the adsorption model (OriginLab, US) was used to analyze the adsorption of heavy metals by adsorbents, Wang et al. [13] believed that the Langmuir model could better describe the adsorption process of $\mathrm{Pb}$ adsorption by sludge incineration ash. El-Enein et al. [14] investigated the adsorption performance of nano-bentonite particles for $\mathrm{Cu}$, and found that the adsorption capacity of $\mathrm{Cu}$ monolayer was $35.46 \mathrm{mg} / \mathrm{g}$, and the adsorption kinetics complied with the pseudo-second-order (PSO) rate equation. Guo et al. [15] studied the kinetic characteristics of biochar adsorption of $\mathrm{Zn}$ and believed that the kinetics of biochar adsorption of $\mathrm{Zn}$ was in line with the PSO kinetic model. Chwastowski et al. [16] believed that the Langmuir model could accurately describe the adsorption process of $\mathrm{Cd}(\mathrm{II}), \mathrm{Mn}$ (II) and $\mathrm{Pb}(\mathrm{II})$ in coffee grounds, and the PSO kinetic model could accurately describe the kinetic process. Alandis et al. [17] studied the kinetics and thermodynamics of bentonite adsorption of heavy metals, and found that the PSO kinetic model was consistent with the adsorption of Fe and Ni. The thermodynamic parameters showed that the adsorption process was spontaneous and endothermic.

Some scholars characterized the adsorption of pollutants from the microscopic aspect and explored the adsorption mechanism of pollutants. Somasundaran and Fuerstenau [18] proposed that the electrodynamic properties of fine particles in solution (zeta potential) are of great significance for understanding the adsorption mechanism of inorganic and organic matter at the compound/solution interface. Tang et al. [19] characterized the loess after adsorption of $\mathrm{Zn}$ by XRD, and found that the mineral components calcite, goethite and kaolinite were the main clay minerals for removing Zn. Alkan et al. [20] measured by zeta potential that the surface of perlite in aqueous solution was negatively charged, and the absolute value of potential was about $38 \mathrm{mV}$. Through potential test, it was found that in inorganic salt solutions $\mathrm{CaCl}_{2}, \mathrm{MgCl}_{2}$ and $\mathrm{Pb}\left(\mathrm{NO}_{3}\right)_{2}$, the absolute value of potential of perlite decreased with the increase in salt solution concentration. Pehlivan et al. [21] used FTIR to analyze the adsorption principle of $\mathrm{Pb}^{2+}$ by hazelnut and almond shell, and believed that the surface of hazelnut and almond shells is heterogeneous, and there are a variety of functional groups that can adsorb $\mathrm{Pb}^{2+}$.

Although there have been many studies on the effects of solution characteristics and temperature on the adsorption characteristics of pollutants in bentonite anti-fouling barrier materials, most of them obtained the adsorption rules of pollutants in the antifouling barrier through experiments, and few explored the adsorption mechanism from the microscopic perspective. In this paper, by studying the reaction temperature, initial concentration and the adsorption time of stone chips-bentonite mixed soil to remove heavy metal zinc features, using the different adsorption model fitting to explore its adsorption mechanism, with the potential revealing the changes of stone chips-a bentonite mixture for evaluating the zinc adsorption mechanism, we discuss the feasibility of the quarry waste as antifouling barrier material.

\section{Material and Test Program}

\subsection{Test Material}

The test uses sodium bentonite, (Yiguo Bentonite Factory, Zhejiang, China) produced in An'ji, Zhejiang Province, the main mineral component is montmorillonite. The free swelling index was $17 \mathrm{~mL} / 2 \mathrm{~g}$, the liquid limit was $218 \%$, and the plastic limit was $43 \%$, Table 1 is the composition of bentonite. The stone chips are the waste material of a quarry, the maximum particle size is less than $5 \mathrm{~mm}$. According to the particle analysis test, the fine particle content is $7.48 \%$, the non-uniformity coefficient $\mathrm{Cu}$ is 15.0 , the curvature coefficient $C_{c}$ is 1.7 , and the maximum dry density is $1.95 \mathrm{~g} / \mathrm{cm}^{3}$ in the compaction test. The content of bentonite in the mixed soil is $7 \%$, and the permeability coefficient is $4.39 \times 10^{-7} \mathrm{~cm} / \mathrm{s}$. 
Table 1. Composition of bentonite.

\begin{tabular}{cccccccc}
\hline $\begin{array}{c}\text { Chemical } \\
\text { Composition }\end{array}$ & $\mathrm{SiO}_{2}$ & $\mathrm{AL}_{2} \mathrm{O}_{3}$ & $\mathrm{CaO}$ & $\mathrm{MgO}$ & $\mathrm{Na}_{2} \mathrm{O}$ & $\mathrm{Fe}_{2} \mathrm{O}_{3}$ & $\mathrm{TiO}_{2}$ \\
\hline Content (\%) & 68.5 & 14.09 & 0.63 & 2.45 & 3.56 & 2.37 & 0.32 \\
\hline
\end{tabular}

\subsection{Zn Standard Curve}

The standard curve was made by atomic adsorption spectrometry. The concentration of the standard curve was set as $0.1,0.2,0.4$ and $1 \mathrm{mg} / \mathrm{L}$ in standard zinc solution of $1000 \mu \mathrm{g} / \mathrm{mL}$, and the standard curve is shown in Figure 1 .

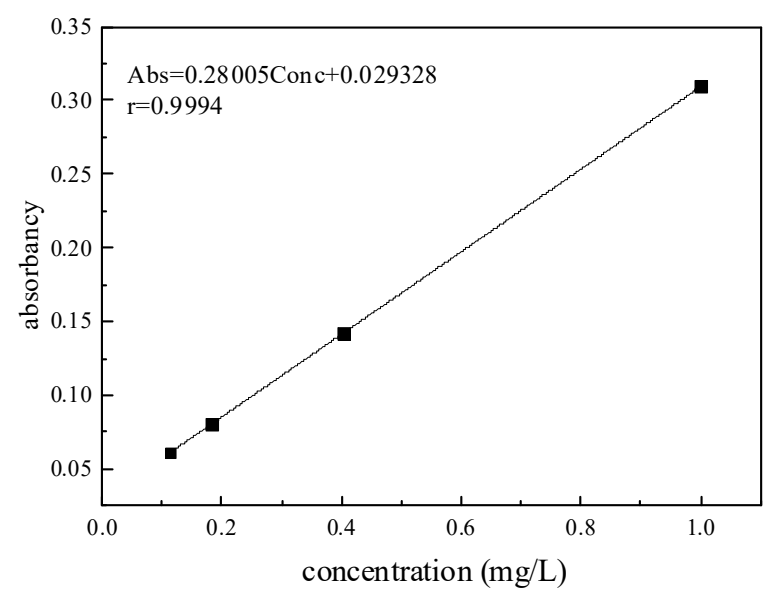

Figure 1. Standard solution curve of $\mathrm{Zn}$.

\subsection{Test Scheme}

Batch equilibrium adsorption test was used to investigate the adsorption characteristics of stone debris - bentonite fouling barrier on heavy metal ions Zn [20]. Adsorption tests are mainly divided into static equilibrium isothermal adsorption and dynamic isothermal adsorption. $\mathrm{Zn}$ ionic solution was prepared by $\mathrm{ZnCl}_{2}$, and the concentration of 8 groups were $3,5,10,30,50,80$ and $100 \mathrm{mmol} / \mathrm{L}$, respectively. The reaction time was $24 \mathrm{~h}$ at 25 , 40 and $55^{\circ} \mathrm{C}$. Dynamic isothermal adsorption tests were conducted at concentrations of 10 and $30 \mathrm{mmol} / \mathrm{L}$, reaction times were set as $0.25,0.5,1,2,6$ and $24 \mathrm{~h}$, respectively, and temperature was $25^{\circ} \mathrm{C}$. The soil-water ratio of both adsorption tests was $1: 20$, using $0.1 \mathrm{M}$ $\mathrm{HCl}$ to adjust the $\mathrm{pH}$ of the reaction system to 5.5. The specific test scheme is shown in Table 2.

Table 2. Test scheme.

\begin{tabular}{cccccc}
\hline Type & $\begin{array}{c}\text { Solid Quality } \\
(\mathbf{g})\end{array}$ & $\begin{array}{c}\text { The Quality of } \\
\text { the Liquid } \\
(\mathbf{g})\end{array}$ & $\begin{array}{c}\text { Solution } \\
\text { Concentration } \\
(\mathbf{m m o l} / \mathbf{L})\end{array}$ & $\begin{array}{c}\text { Time } \\
\mathbf{( h )}\end{array}$ & $\mathbf{T}\left({ }^{\circ} \mathbf{C}\right)$ \\
\hline & & & $3,5,10$, & & 25 \\
Static balance & 10 & 200 & $30,50,80,100$ & 24 & 40 \\
Dynamic adsorption & & & 10,30 & $0.25,0.5,1,2,6,24$ & 55 \\
& & - & $3,5,10$, & - & 25 \\
Potential & - & & $30,50,80,100$ & - & 40 \\
& & & & & 55 \\
\hline
\end{tabular}




\subsection{Adsorption Parameters}

The adsorption removal rate $R P$ and adsorption capacity $q_{e}$ of the mixed soil on heavy metal $\mathrm{Zn}$ were calculated using Equations (1) and (2):

$$
\begin{gathered}
R P=\frac{C_{0}-C_{\mathrm{e}}}{C_{0}} \times 100 \% \\
q_{e}=\frac{C_{0}-C_{s}}{m_{s}} V
\end{gathered}
$$

where $R P$ is the adsorption removal rate $(\%), C_{0}$ is the initial concentration of pollutants $(\mathrm{mg} / \mathrm{L}), C_{\mathrm{e}}$ is the concentration in the equilibrium state $(\mathrm{mg} / \mathrm{L}), q_{e}$ is the unit adsorption capacity of soil sample $(\mathrm{mg} / \mathrm{g}), m_{s}$ is the mass of adsorbent $(\mathrm{g})$, and $V$ is the volume of solution $(\mathrm{mL})$.

The adsorption capacity $q_{t}$ of the mixed soil on heavy metal $\mathrm{Zn}$ at any time is:

$$
q_{t}=\frac{C_{0}-C_{t}}{m_{s}} V
$$

where $q_{t}$ is the adsorption capacity at any time $(\mathrm{mg} / \mathrm{g})$, and $C_{t}$ is the concentration of $\mathrm{Zn}$ in the centrifugal supernatant at time " $\mathrm{t}$ " $(\mathrm{mg} / \mathrm{L})$.

\section{Test Results and Discussion}

\subsection{Static Adsorption}

3.1.1. Effect of Temperature and Concentration on Adsorption Property of Mixed Soil

The relationship between the initial concentration of $\mathrm{Zn}$ and the adsorption removal rate at $25^{\circ} \mathrm{C}, 40^{\circ} \mathrm{C}$ and $55^{\circ} \mathrm{C}$ is shown in Figure 2. As can be seen from the figure, with the increase in the initial concentration of pollutants, the overall adsorption removal rate of $\mathrm{Zn}$ by the mixture showed a downward trend. For example, at $25^{\circ} \mathrm{C}, 40^{\circ} \mathrm{C}$ and $55^{\circ} \mathrm{C}$, the adsorption removal rate decreased from $98.45 \%, 99.17 \%$ and $99.72 \%$ at $3 \mathrm{mmol} / \mathrm{L}$ to $71.21 \%, 86.41 \%$ and $95.56 \%$ at $100 \mathrm{mmol} / \mathrm{L}$, respectively. When the initial concentration of $\mathrm{Zn}$ is constant, the adsorption removal rate increases with the increase in temperature. For example, when the initial concentration of $\mathrm{Zn}$ was $50 \mathrm{mmol} / \mathrm{L}$, the adsorption removal rates were $83.62 \%, 90.64 \%$ and $96.97 \%$ at $25{ }^{\circ} \mathrm{C}, 40{ }^{\circ} \mathrm{C}$ and $55^{\circ} \mathrm{C}$, respectively. With the increase in the initial concentration, the increasing trend of the temperature on the adsorption removal rate of $\mathrm{Zn}$ in the mixed soil was more significant.

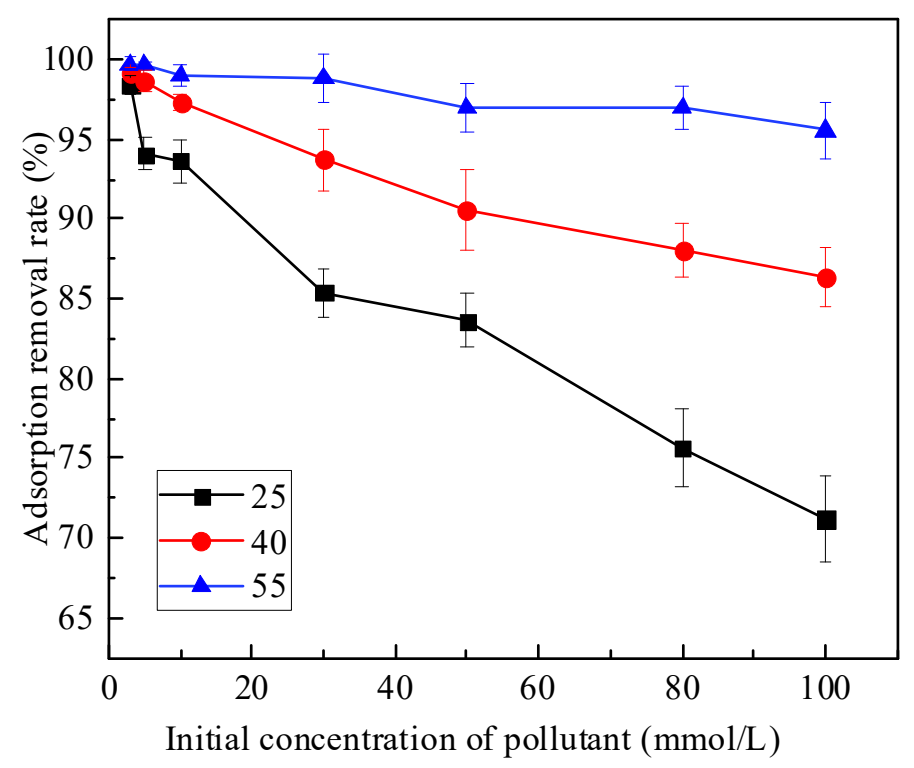

Figure 2. Relationship between initial concentration and adsorption removal rate. 
At $25{ }^{\circ} \mathrm{C}, 40{ }^{\circ} \mathrm{C}$ and $55^{\circ} \mathrm{C}$, the adsorption concentration of mixed soil on $\mathrm{Zn}$ (the adsorption strength of mixed soil on $\mathrm{Zn}$ in solutions with different concentrations) and the change rule of initial concentration are shown in Figure 3. At different temperatures, the adsorption concentration of $\mathrm{Zn}$ increased with the increase in the initial concentration of $\mathrm{Zn}$. When the temperature was $25^{\circ} \mathrm{C}, 40^{\circ} \mathrm{C}$ and $55^{\circ} \mathrm{C}$ and the initial concentration was 30 and $80 \mathrm{mmol} / \mathrm{L}$, the adsorption concentration of $\mathrm{Zn}$ by the mixed soil was 25.57, 28.08, 29.60 and $60.42,70.37,77.42 \mathrm{mmol} / \mathrm{L}$, respectively. Temperature has a significant effect on the adsorption concentration of $\mathrm{Zn}$ in the mixed soil. When the concentration is fixed, the adsorption concentration of $\mathrm{Zn}$ in the mixed soil increases with the increase in temperature. When the concentration is $100 \mathrm{mmol} / \mathrm{L}$, the concentration of $\mathrm{Zn}$ in the mixed soil is 71.09 , 86.27 and $95.40 \mathrm{mmol} / \mathrm{L}$ at $25^{\circ} \mathrm{C}, 40{ }^{\circ} \mathrm{C}$ and $55^{\circ} \mathrm{C}$, respectively.

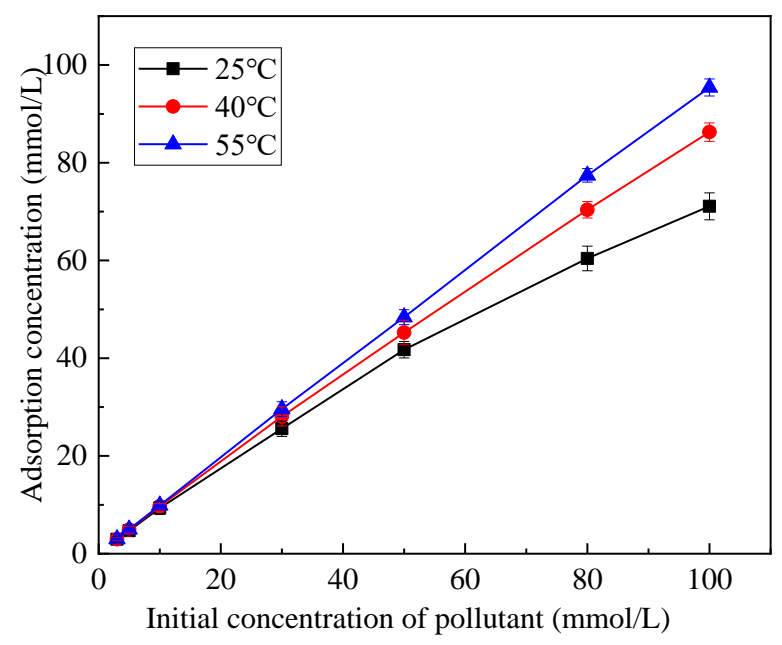

Figure 3. Relationship between initial concentration and adsorption concentration.

\subsubsection{Adsorption Model of Zn by Mixed Soil}

The Langmuir model, Freundlich model and Dubinin-Radushkevich (D-R) model were used to fit the isothermal adsorption data, respectively, in order to investigate the maximum adsorption amount of $\mathrm{Zn}$ and the adsorption mechanism of the mixed soil. The Equations of the three models are shown in Equations (4)-(8).

(1) Langmuir model

$$
\frac{c_{e}}{q_{e}}=\frac{1}{k_{L} q_{m}}+\frac{c_{e}}{q_{m}}
$$

where $k_{L}$ is the Langmuir isothermal parameter $(\mathrm{L} / \mathrm{mg})$, and $q_{m}$ is the maximum adsorption capacity (mg/g) [22,23].

(2) Freundlich model

$$
q_{e}=k_{F} C_{e}^{\frac{1}{n}}
$$

where $k_{F}$ is the Freundlich model constant $(\mathrm{L} / \mathrm{g})$ related to adsorption capacity, and $n$ is the empirical constant, usually greater than 1 . In this case, adsorption is mainly physical process, and the larger the value is, the stronger the non-linearity of the adsorption model is [24].

(3) D-R model

$$
\begin{gathered}
\ln q_{e}=\ln q_{m}-k \varepsilon^{2} \\
\varepsilon=R T \ln \left(1+\frac{1}{c_{e}}\right) \\
E=-\frac{1}{\sqrt{2 k}}
\end{gathered}
$$


where $k$ is the relevant model constant $\left(\mathrm{mol}^{2} \cdot \mathrm{kJ}^{-2}\right), q_{m}$ is the maximum adsorption capacity $(\mathrm{mg} / \mathrm{g}), \varepsilon$ is the Polanyi potential, is related to the equilibrium concentration $c_{e}, R$ is the ideal gas constant $\left(\mathrm{J} \cdot \mathrm{mol}^{-1} \cdot \mathrm{K}^{-1}\right), T$ is the thermodynamic temperature $(\mathrm{K})$, $E$ is the average adsorption free energy $(\mathrm{kJ} / \mathrm{mol})$. When $1 \mathrm{~kJ} / \mathrm{mol}<|E|<8 \mathrm{~kJ} / \mathrm{mol}$, for physical adsorption; $8 \mathrm{~kJ} / \mathrm{mol}<|E|<16 \mathrm{~kJ} / \mathrm{mol}$, ion exchange; $|E|>16.0 \mathrm{~kJ} / \mathrm{mol}$, chemical adsorption [25-29].

The Langmuir model, Freundlich model and D-R model were, respectively, fitted for the adsorption of heavy metal $\mathrm{Zn}$ by mixed soil at $25^{\circ} \mathrm{C}, 40^{\circ} \mathrm{C}$ and $55^{\circ} \mathrm{C}$, and the fitting results are shown in Figure 4. As can be seen from Figure 4, each model can well reflect the adsorption capacity at different temperatures. The fitting parameters are shown in Table 3. According to the correlation coefficient $\mathrm{R}^{2}$ in Table 3, Langmuir models can effectively reflect the adsorption characteristics of heavy metal $\mathrm{Zn}$ by mixed soil at temperatures of 25 , 40 and $55^{\circ} \mathrm{C}$. Additionally, the constant $\mathrm{n}$ in Freundlich model is greater than 1, indicating that the adsorption of $\mathrm{Zn}$ by mixed soil is nonlinear. The correlation coefficient $\mathrm{R}^{2} \geq 0.96$ of Langmuir model fitting, and the maximum adsorption capacity of monolayer soil at 25, 40 and $55^{\circ} \mathrm{C}$ is $127.56,179.02$ and $179.38 \mathrm{mg} / \mathrm{g}$, respectively. The D-R model is used to calculate the adsorption energy of mixed soil for $\mathrm{Zn}$ at 25,40 and $55^{\circ} \mathrm{C}$. The $|\mathrm{E}|$ is between 8 and $16 \mathrm{~kJ} / \mathrm{mol}$, indicating that the adsorption of $\mathrm{Zn}$ by mixed soil is chemical adsorption, and there is ion exchange.

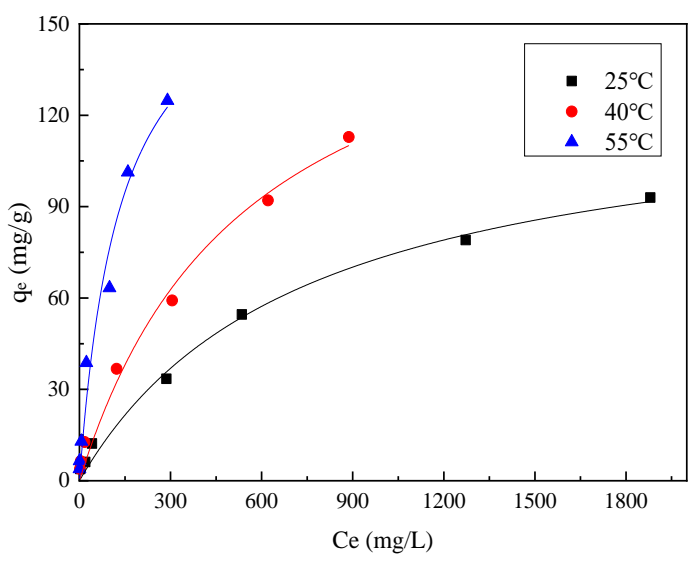

(a) Langmuir

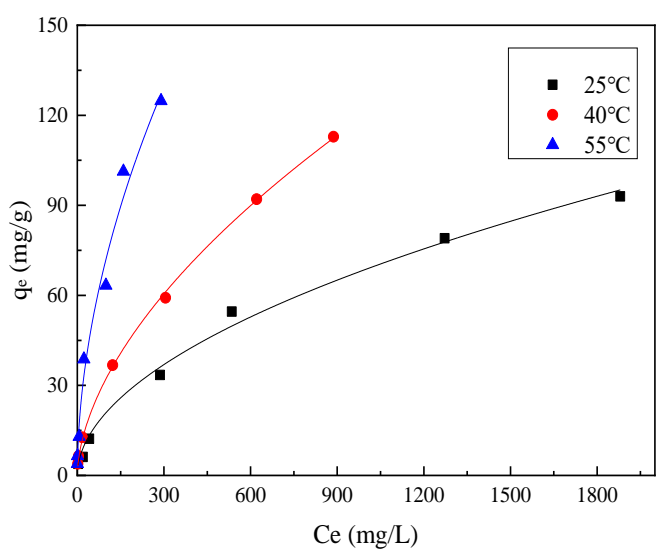

(b) Freundlich

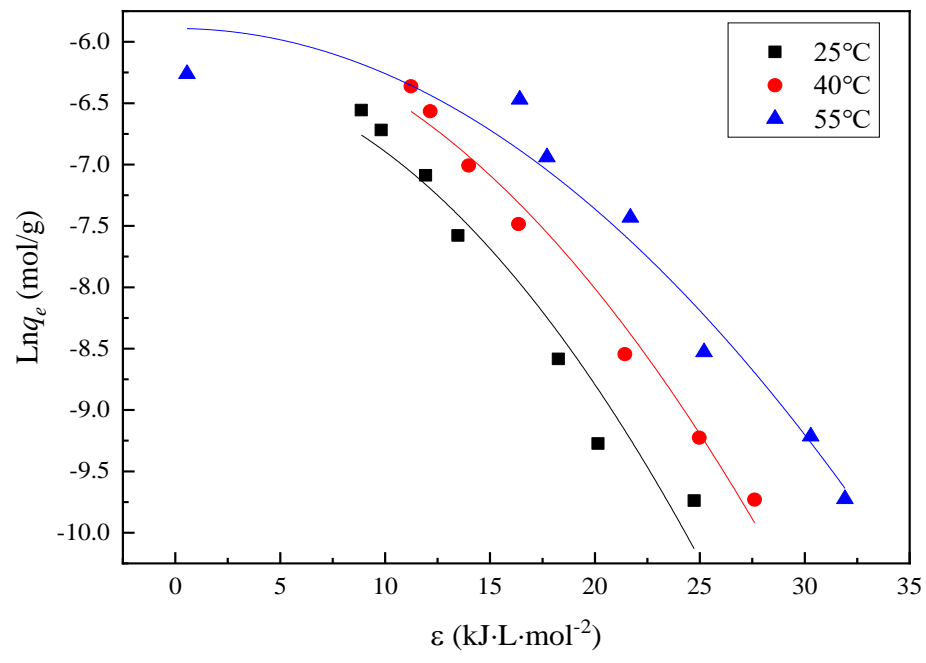

(c) D-R

Figure 4. Adsorption model. 
Table 3. Adsorption model parameters.

\begin{tabular}{ccccc}
\hline Model & Parameter & $\mathbf{2 5}{ }^{\circ} \mathbf{C}$ & $\mathbf{4 0}{ }^{\circ} \mathbf{C}$ & $\mathbf{5 5}{ }^{\circ} \mathbf{C}$ \\
\hline \multirow{3}{*}{ Langmuir } & $k_{L}(\mathrm{~L} / \mathrm{mg})$ & $1.360 \times 10^{-3}$ & $1.800 \times 10^{-3}$ & $7.470 \times 10^{-3}$ \\
& $q_{m}(\mathrm{mg} / \mathrm{g})$ & 127.560 & 179.014 & 179.383 \\
& $\mathrm{R}^{2}$ & 0.991 & 0.985 & 0.966 \\
Freundlich & $k_{F}$ & 1.952 & 2.329 & 6.317 \\
& $\mathrm{n}$ & 1.938 & 1.751 & 1.890 \\
& $\mathrm{R}^{2}$ & 0.993 & 0.999 & 0.983 \\
D-R & $k\left(\mathrm{~mol}^{2} \cdot \mathrm{kJ}-2\right)$ & $6.33 \times 10^{-3}$ & $5.27 \times 10^{-3}$ & $3.680 \times 10^{-3}$ \\
& $q_{m}(\mathrm{mg} / \mathrm{g})$ & $1.907 \times 10^{-3}$ & $2.733 \times 10^{-3}$ & $2.764 \times 10^{-3}$ \\
& $|\mathrm{E}|(\mathrm{kJ} / \mathrm{mol})$ & 8.889 & 9.740 & 11.656 \\
& $\mathrm{R}^{2}$ & 0.939 & 0.980 & 0.952 \\
\hline
\end{tabular}

\subsection{Dynamic Adsorption}

\subsubsection{Dynamic Adsorption Characteristic}

The relationship between the adsorption removal rate of $\mathrm{Zn}$ by mixed soil and the adsorption time is shown in Figure 5. When the initial concentration was 10 and $30 \mathrm{mmol} / \mathrm{L}$, the adsorption removal rates increased with the increase in time and finally tended to be stable. For the adsorption of $\mathrm{Zn}$ by the mixed soil, the adsorption rate is faster in the early stage, within $15 \mathrm{~min}$, and the adsorption removal rate changes greatly, then increases slowly, and reaches the adsorption equilibrium in about $6 \mathrm{~h}$. If the initial concentration of $\mathrm{Zn}$ was $30 \mathrm{mmol} / \mathrm{L}$, the adsorption removal rates were $63.49 \%, 73.06 \%, 80.29 \%, 89.64 \%$, $93.59 \%$ and $93.66 \%$ at $0.25,0.5,1 \mathrm{~h}, 2,6$ and $24 \mathrm{~h}$, respectively. When the adsorption time is constant, the adsorption removal rate of $\mathrm{Zn}$ decreases with the increase in the concentration. For example, when the adsorption time is $0.5 \mathrm{~h}$, the adsorption removal rate decreases from $73.06 \%$ at $10 \mathrm{mmol} / \mathrm{L}$ to $57.17 \%$ at $30 \mathrm{mmol} / \mathrm{L}$, respectively.

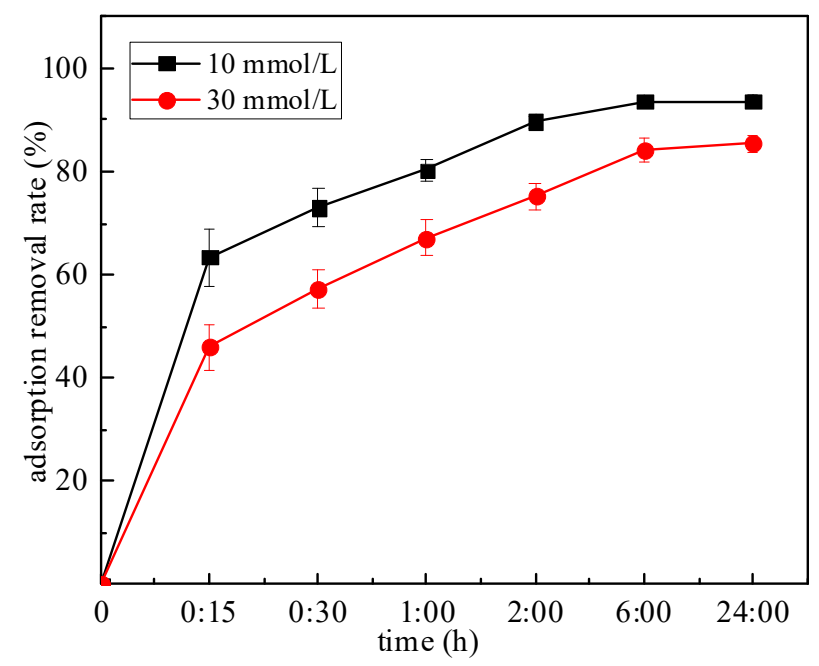

Figure 5. Relationship between adsorption time and removal rate.

\subsubsection{Dynamic Adsorption Model}

To understand the adsorption mechanism of $\mathrm{Zn}$ on the mixture, sorption kinetics were analyzed using pseudo first order model (PFO), pseudo second order model (PSO) and intra-particle diffusion model. The expressions are shown in (9)-(11). The influence of concentration on the adsorption rate is explored and the control mechanism of heavy metal $\mathrm{Zn}$ adsorption in soil is revealed.

(1) Pseudo first order (PFO) model

$$
q_{t}=q_{e}\left(1-e^{-k_{1} t}\right)
$$


where $q_{t}$ is the adsorption capacity of unit soil at any time $(\mathrm{mg} / \mathrm{g})$, and $k_{1}$ is the PFO model constant $\left(\mathrm{g} \cdot \mathrm{mg} \cdot \mathrm{h}^{-1}\right)$. [30]

(2) Pseudo second order (PSO) model

$$
\frac{t}{q_{t}}=\frac{1}{k_{2} q_{e}^{2}}+\frac{t}{q_{e}}
$$

where $k_{2}$ is the PSO model constant $\left(\mathrm{g} \cdot \mathrm{mg} \cdot \mathrm{h}^{-1}\right), t$ is time (h) [31].

(3) Intra-particle diffusion (IP) model In general, the diffusion energy in the particles determines the rate of the whole adsorption process for the porous adsorption materials. The simplified intra-particle diffusion equation is as follows:

$$
q_{t}= \begin{cases}k_{\mathrm{int}} t^{0.5}+C & \left(t<t_{e}\right) \\ q_{e} & \left(t \geq t_{e}\right)\end{cases}
$$

where $k_{\text {int }}$ is the diffusion rate constant within the particle $\left(\mathrm{Mg} \cdot \mathrm{g}^{-1} \cdot \mathrm{min}^{-0.5}\right), \mathrm{C}$ is the intercept, which is related to the thickness of the boundary layer [32].

Figures 6-8 are the fitting curves of the PFO model, the PSO model and the intraparticle diffusion model for the adsorption of $\mathrm{Zn}$ by the mixed soil, respectively. According to the fitting correlation coefficient $\mathrm{R}^{2}$ in Table 4 , the adsorption of $\mathrm{Zn}$ by the mixed soil with different initial concentrations conforms to the PSO model, and the $\mathrm{R}^{2} \geq 0.99$. The adsorption parameter $\mathrm{K}_{2}$ of mixed soil with an initial concentration of $10 \mathrm{mmol} / \mathrm{L} \mathrm{Zn}$ was $0.967 \mathrm{~g} \cdot \mathrm{mg} \cdot \mathrm{h}^{-1}$, which was higher than that of $0.171 \mathrm{~g} \cdot \mathrm{mg} \cdot \mathrm{h}^{-1}$ with an initial concentration of $30 \mathrm{mmol} / \mathrm{L}$, indicating that the higher the initial concentration of $\mathrm{Zn}$, the lower the adsorption rate of $\mathrm{Zn}$ in mixed soil.

It can be seen from Figure 8 that the curve is divided into two sections, corresponding to non-equilibrium adsorption section and equilibrium adsorption section, respectively. When the concentration is 10 and $30 \mathrm{mmol} / \mathrm{L}, t_{e}$ is $2 \mathrm{~h}$ and $6 \mathrm{~h}$, respectively, the fitting equilibrium adsorption amount is 12.05 and $33.20 \mathrm{mg} / \mathrm{g}$, respectively, which is close to the 12.23 and $33.45 \mathrm{mg} / \mathrm{g}$ obtained from the test. According to the fitting parameters of the intra-particle diffusion model in Table 4, $\mathrm{C}$ of the mixed soil for the two initial concentrations of $\mathrm{Zn}$ is not equal to 0 , and the non-equilibrium adsorption stage curve does not pass through the origin, indicating that the adsorption mode of the mixed soil for $\mathrm{Zn}$ is controlled by both intra-particle diffusion and membrane diffusion. The intra-particle diffusion model can reflect the adsorption process and rate. The adsorption process is composed of two successive steps. The first stage is a gradual adsorption stage, and the adsorption rate depends on the diffusion rate. The second stage is the equilibrium stage; the residual $\mathrm{Zn}^{2+}$ concentration in the solution decreases, the concentration difference between soil and water decreases, the diffusion rate between particles decreases, and the adsorption reaction basically reaches equilibrium [31].

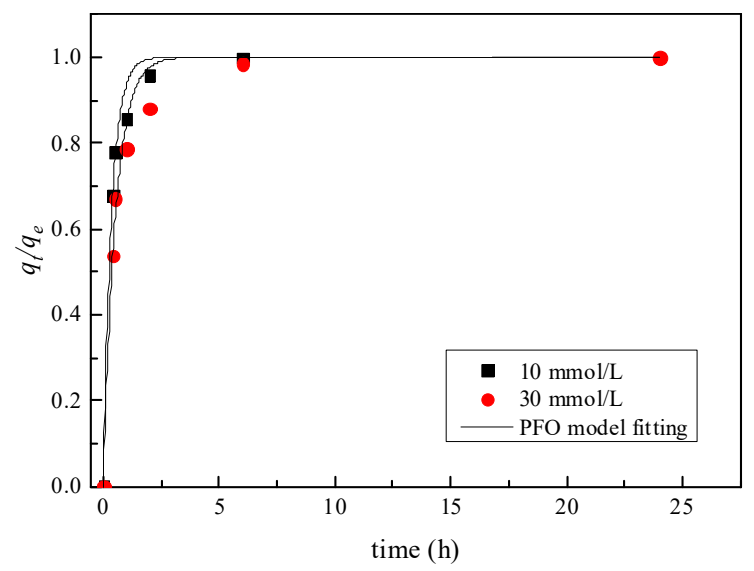

Figure 6. Pseudo first order model. 


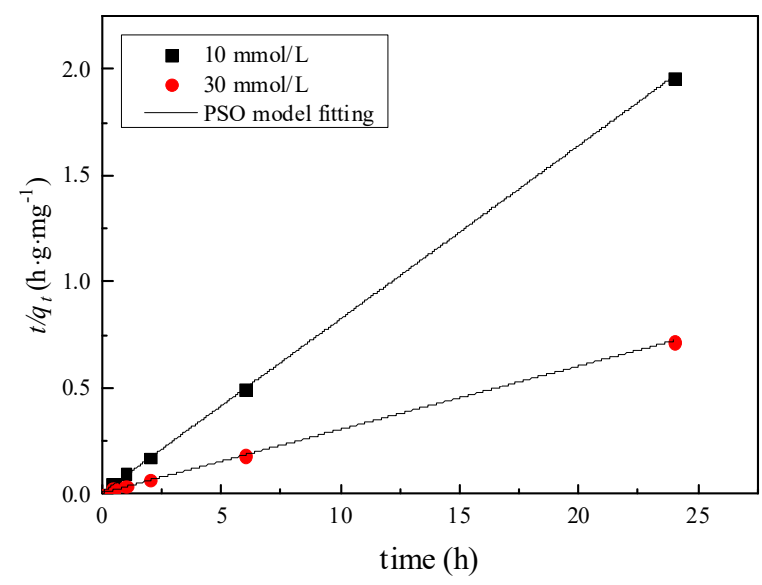

Figure 7. Pseudo second order model.

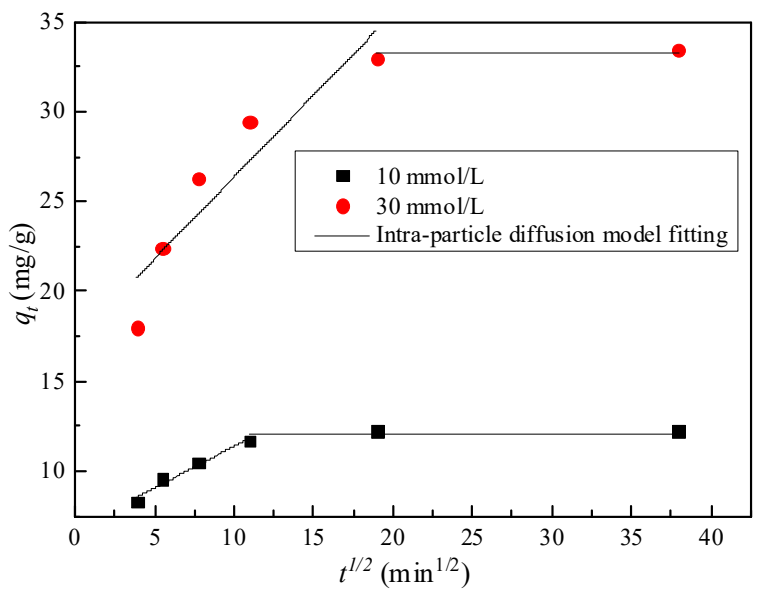

Figure 8. Intra-particle diffusion model.

Table 4. Kinetic model parameters of adsorption.

\begin{tabular}{|c|c|c|c|c|c|c|c|c|}
\hline \multirow{2}{*}{$\begin{array}{c}\mathrm{Zn} \\
\begin{array}{c}\text { Conc. } \\
\text { Concentration } \\
(\mathrm{mmol} / \mathrm{L})\end{array}\end{array}$} & \multicolumn{2}{|c|}{$\begin{array}{l}\text { PFO Pseudo First } \\
\text { Order Model }\end{array}$} & \multicolumn{2}{|c|}{$\begin{array}{l}\text { PSO Pseudo Second } \\
\text { Order Model }\end{array}$} & \multicolumn{4}{|c|}{ Intra-Particle Diffusion Model } \\
\hline & $\begin{array}{c}\mathrm{k}_{1} \\
\left(\mathrm{~g} \cdot \mathrm{mg}^{-} \mathrm{h}^{-1}\right)\end{array}$ & $\mathbf{R}^{2}$ & $\begin{array}{c}k_{2} \\
\left(\mathrm{~g} \cdot \mathrm{mg} \cdot \mathrm{h}^{-1}\right)\end{array}$ & $\mathbf{R}^{2}$ & $\frac{k_{\text {int }}}{\left(\mathrm{mg} \cdot \mathrm{g}^{-1} \cdot \min ^{-0.5}\right)}$ & C & $\begin{array}{c}q_{e} \\
(\mathrm{mg} / \mathrm{g})\end{array}$ & $\mathbf{R}^{2}$ \\
\hline 10 & 2.76 & 0.99 & 0.97 & 0.99 & 0.47 & 6.75 & 12.05 & 0.96 \\
\hline 30 & 1.88 & 0.98 & 0.17 & 0.99 & 0.91 & 17.28 & 33.20 & 0.81 \\
\hline
\end{tabular}

\subsection{Adsorption Thermodynamics}

According to the thermodynamic parameters of $\Delta G_{0}, \Delta H_{0}$ and $\Delta S_{0}$, the effect of temperature on the adsorption of $\mathrm{Zn}$ on the mixed soil is analyzed. The thermodynamic parameters are calculated by Equations (12) and (13).

$$
\begin{aligned}
& \Delta G_{0}=\Delta H_{0}-T \Delta S_{0} \\
& \ln K_{c}=\frac{\Delta S_{0}}{R}-\frac{\Delta H_{0}}{R T}
\end{aligned}
$$

where $K_{c}$ is the partition coefficient (the ratio of solid phase equilibrium concentration to solution equilibrium concentration), $T$ is the temperature $(\mathrm{K}), R$ is the ideal gas constant $\left(8.314 \mathrm{~J} \cdot \mathrm{mol}^{-1} \cdot \mathrm{K}^{-1}\right), \Delta G_{0}$ is Gibbs energy change $\left(\mathrm{kJ} \cdot \mathrm{mol}^{-1}\right), \Delta H_{0}$ is the enthalpy change $\left(\mathrm{kJ} \cdot \mathrm{mol}^{-1}\right)$, and $\Delta S_{0}$ is the entropy change $\left(\mathrm{kJ} \cdot \mathrm{mol}^{-1}\right)$. 
The reaction is carried out under isothermal and isobaric conditions. The degree of difficulty of the reaction is determined by $\Delta G_{0}$ to a certain extent, the value of $\Delta G_{0}$ is negative and the larger the absolute value, the easier the reaction occurs. $\Delta H_{0}$ is " + " for endothermic reaction, and "-" for exothermic reaction. $\Delta S_{0}$ is a measure of the disorder of a system, as a criterion for judging the direction of spontaneous reactions.

The fitting results of the thermodynamic model for the adsorption of $\mathrm{Zn}$ by mixed soil are shown in Figure 9. In the figure, the slope and intercept of the fitting line between $\ln \mathrm{Kc}_{\mathrm{c}}$ and $1 / \mathrm{T}$ were calculated for the $\Delta H_{0}$ and $\Delta S_{0}$. The adsorption thermodynamic parameters are listed in Table 5. The concentration of $\mathrm{Zn}$ is constant and all of $\Delta G_{0}$ are negative and decrease with the increase in temperature, indicating that the adsorption of $\mathrm{Zn}$ by mixed soil is spontaneous and spontaneously increasing with the increase in temperature. For example, when the concentration of $\mathrm{Zn}$ was $30 \mathrm{mmol} / \mathrm{L}$, the values of $\Delta \mathrm{G}_{0}$ at $25{ }^{\circ} \mathrm{C}$, $40{ }^{\circ} \mathrm{C}$ and $55^{\circ} \mathrm{C}$ were $-4.020 \mathrm{~kJ} / \mathrm{mol},-7.836 \mathrm{~kJ} / \mathrm{mol}$ and $-11.651 \mathrm{~kJ} / \mathrm{mol}$, respectively. The $\Delta H_{0}$ of $\mathrm{Zn}$ adsorption reaction was positive at different concentrations, indicating that the adsorption reaction was an endothermal process. For example, when the initial concentration of $\mathrm{Zn}$ was 3, 5, 10, 30, 50, 80 and $100 \mathrm{mmol} / \mathrm{L}$, the values of $\Delta H_{0}$ were 46.864, $82.171,52.153,71.823,49.457,62.658$ and $58.498 \mathrm{~kJ} / \mathrm{mol}$, respectively. Therefore, increasing the temperature was beneficial to the adsorption of $\mathrm{Zn}$ by mixed soil. The values of $\Delta S_{0}$ of $\mathrm{Zn}$ adsorption by mixed soil are all positive, indicating that the reaction is an irreversible process driven by entropy and desorption is not easy to occur [33].

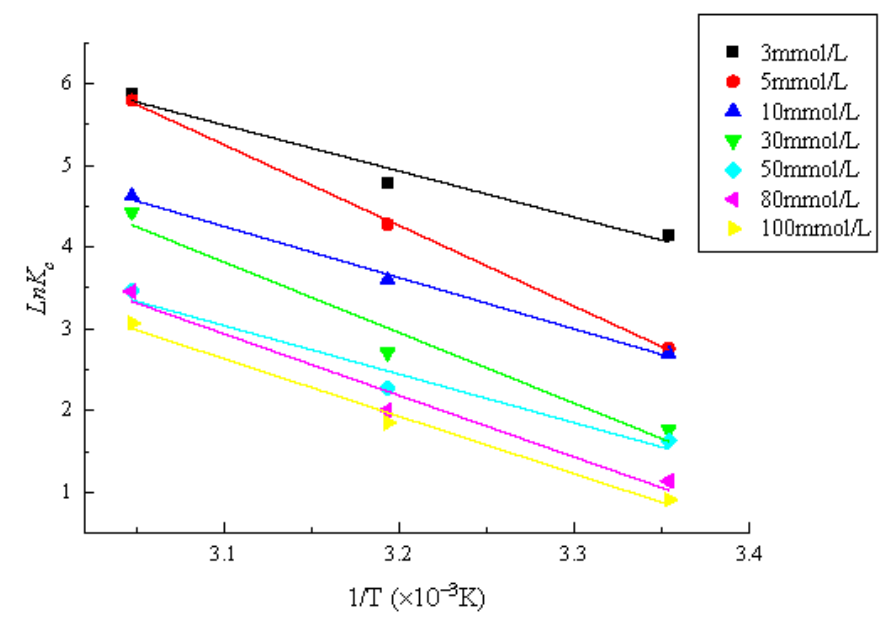

Figure 9. Adsorption thermodynamic model.

Table 5. Adsorption thermodynamic parameters.

\begin{tabular}{|c|c|c|c|c|c|}
\hline $\mathrm{C}_{0}(\mathrm{mmol} / \mathrm{L})$ & $\mathrm{T}\left({ }^{\circ} \mathrm{C}\right)$ & $\Delta G_{0}(\mathrm{~kJ} / \mathrm{mol})$ & $\Delta H_{0}(\mathrm{~kJ} / \mathrm{mol})$ & $\Delta S_{0}\left(\mathrm{~J} \cdot \mathrm{mol}^{-1} \mathrm{~K}^{-1}\right)$ & $\mathbf{R}^{2}$ \\
\hline \multirow{4}{*}{3} & 25 & -10.069 & \multirow{4}{*}{46.864} & \multirow{3}{*}{190.955} & \multirow{3}{*}{0.935} \\
\hline & 40 & -12.934 & & & \\
\hline & 55 & -15.798 & & & \\
\hline & 25 & -6.795 & & & \multirow{4}{*}{0.998} \\
\hline \multirow[t]{3}{*}{5} & 40 & -11.271 & \multirow[t]{3}{*}{82.171} & \multirow[t]{3}{*}{298.393} & \\
\hline & 55 & -15.747 & & & \\
\hline & 25 & -6.591 & & & \\
\hline \multirow[t]{3}{*}{10} & 40 & -9.547 & \multirow[t]{3}{*}{52.153} & \multirow[t]{3}{*}{197.030} & \multirow[t]{3}{*}{0.992} \\
\hline & 55 & -12.502 & & & \\
\hline & 25 & -4.020 & & & \\
\hline \multirow[t]{2}{*}{30} & 40 & -7.836 & \multirow[t]{2}{*}{71.823} & \multirow[t]{2}{*}{254.379} & \multirow[t]{2}{*}{0.926} \\
\hline & 55 & -11.651 & & & \\
\hline
\end{tabular}


Table 5. Cont.

\begin{tabular}{cccccc}
\hline $\mathrm{C}_{\mathbf{0}}(\mathbf{m m o l} / \mathrm{L})$ & $\mathbf{T}\left({ }^{\circ} \mathbf{C}\right)$ & $\Delta \boldsymbol{G}_{0}(\mathbf{k J} / \mathbf{m o l})$ & $\Delta \boldsymbol{H}_{0}(\mathbf{k J} / \mathbf{m o l})$ & $\Delta \boldsymbol{S}_{0}\left(\mathrm{~J} \cdot \mathbf{m o l}^{-\mathbf{1}} \mathbf{K}^{-\mathbf{1}}\right)$ & $\mathbf{R}^{\mathbf{2}}$ \\
\hline \multirow{2}{*}{50} & 25 & -3.788 & & & \\
& 40 & -6.467 & 49.457 & 178.585 & 0.921 \\
\multirow{2}{*}{80} & 55 & -9.146 & & & \\
& 25 & -2.537 & & 218.665 & 0.942 \\
& 40 & -5.817 & 62.658 & & \\
100 & 55 & -9.097 & & 203.231 & 0.980 \\
& 25 & -2.095 & & & \\
\hline
\end{tabular}

\section{Analysis of Adsorption Mechanism}

\subsection{Zeta Potential}

Figure 10 shows the relationship between the initial concentration of heavy metal $\mathrm{Zn}$ and the zeta potential of the suspension system of mixed soil at $25^{\circ} \mathrm{C}, 40^{\circ} \mathrm{C}$ and $55^{\circ} \mathrm{C}$. It can be seen from the figure that at $25^{\circ} \mathrm{C}, 40^{\circ} \mathrm{C}$ and $55^{\circ} \mathrm{C}$, zeta potential gradually increases with the increase in the initial concentration of $\mathrm{Zn}$. For example, when the temperature was $25^{\circ} \mathrm{C}, 40^{\circ} \mathrm{C}$ and $55^{\circ} \mathrm{C}$, the zeta potential value increased from $-22.4 \mathrm{mV},-20.9 \mathrm{mV}$ and $-19.5 \mathrm{mV}$ at the initial concentration of $3 \mathrm{mmol} / \mathrm{L}$ to $-8.61 \mathrm{mV},-7.26 \mathrm{mV}$ and $-1.53 \mathrm{mV}$ at the concentration of $100 \mathrm{mmol} / \mathrm{L}$, respectively. When the initial concentration of $\mathrm{Zn}$ is constant, the zeta potential of the suspension system of mixed soil and $\mathrm{Zn}$ increases with the increase in temperature. For example, when the concentration of $\mathrm{Zn}$ is $50 \mathrm{mmol} / \mathrm{L}$, the zeta potential increases from $-14.1 \mathrm{mV}$ at $25^{\circ} \mathrm{C}$ to $-10.4 \mathrm{mV}$ at $40{ }^{\circ} \mathrm{C}$ and $-6.64 \mathrm{mV}$ at $55^{\circ} \mathrm{C}$. Adsorption of $\mathrm{Zn}$ by mixed soil is an endothermic process, and the amount of adsorption increases with the increase in reaction temperature. With the increase in reaction temperature, on the one hand, the number of active points available on the surface of the adsorbent is increased, and more metal cations can be adsorbed [34]. On the other hand, the thickness of double electric layer on the surface of the mixed soil decreases, and the negative potential on the surface of the soil particles weakens, which is caused by the adsorption of more cations.

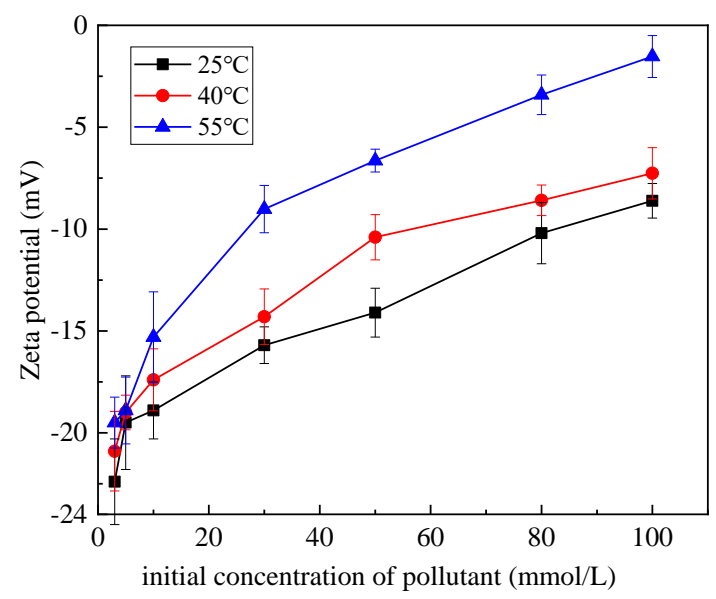

Figure 10. Influence of temperature on zeta potential of suspension system.

\subsection{X-ray Diffraction}

Figure 11 shows the relationship between the initial concentration of pollutants and XRD (Bruke D8 Advance, Sigersdorff, Germany) $\left(25^{\circ} \mathrm{C}\right)$. It can be seen from the figure that in $2 \theta=10^{\circ}-15^{\circ}$, the crystal plane characteristic diffraction peak of the bentonite sample with the initial pollutant concentration of $50 \mathrm{mmol} / \mathrm{L}$ shifted to the left as a whole compared with the low initial concentration, and a new diffraction peak appeared, indicating that 
$\mathrm{Zn}^{2+}$ entered the interlayer of bentonite and interlayer adsorption existed. At $2 \theta=20^{\circ}-50^{\circ}$, the peak of the characteristic diffraction peak decreases, and there are different degrees of characteristic peaks decreasing or disappearing, indicating that the bentonite undergoes ion exchange with the increase in the $\mathrm{Zn}^{2+}$ concentration in the pollutant, and the original crystallinity of the sample has changed, indicating that ion exchange occurs between $\mathrm{Zn}^{2+}$ and bentonite surface ions.

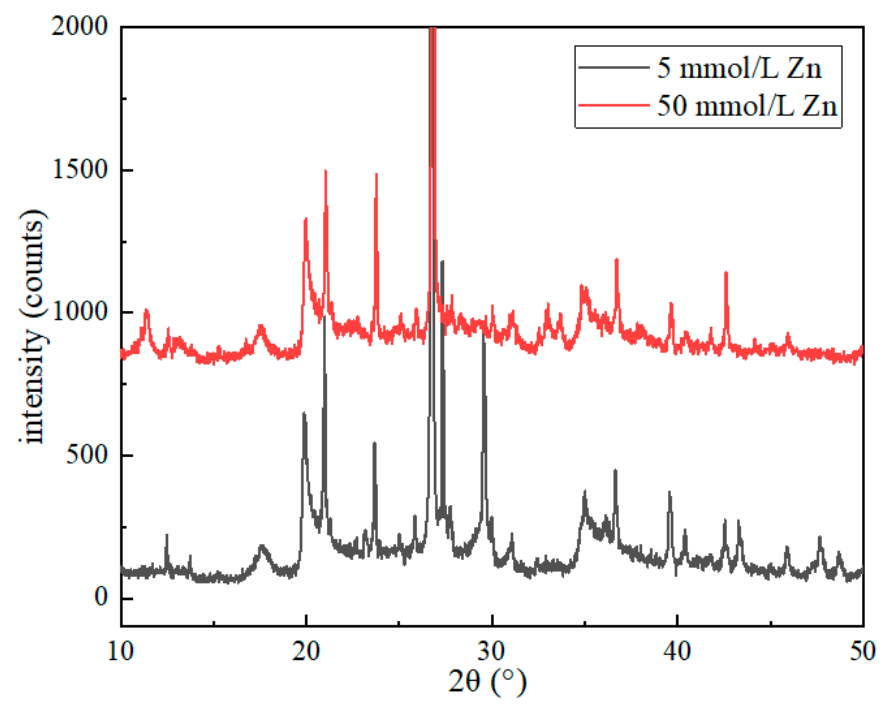

Figure 11. Relationship between initial concentration of pollutants and XRD patterns $\left(25^{\circ} \mathrm{C}\right)$.

\subsection{The Fourier Transform Infrared Spectroscopy}

The FTIR (Thermo Scientific Nicolet 10, Waltham, MA, USA) diagram of bentonite adsorbing different concentrations of $\mathrm{Zn}^{2+}\left(25^{\circ} \mathrm{C}\right)$ is shown in Figure 12. Scanning from 4000 to $400 \mathrm{~cm}^{-1}$, the basic framework of bentonite remains unchanged after adsorbing different concentrations of $\mathrm{Zn}^{2+}$. Furthermore, $3448 \mathrm{~cm}^{-1}$ is the elastic vibration of the water molecules $\mathrm{H}-\mathrm{O}-\mathrm{H}$ between the bentonite layers, and near $1427 \mathrm{~cm}^{-1}$ is the special vibration of the Si-O-Si bond. The results show that the changes of the absorption peak before and after the absorption of different concentrations of $\mathrm{Zn}^{2+}$ by the bentonite are basically the same-after adsorption, heavy metal ions enter the interlayer. When the concentration of $\mathrm{Zn}^{2+}$ increases, the peak intensity of the M Al-OH (M means metal cation) shock peak at $877 \mathrm{~cm}^{-1}$ decreases, which means that ion exchange has occurred between bentonite and $\mathrm{Zn}^{2+}$.

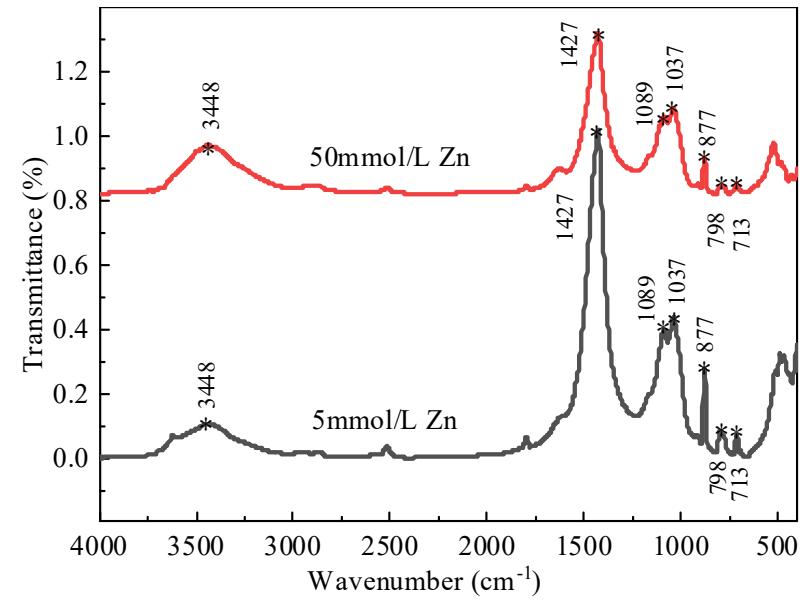

Figure 12. FTIR spectra of bentonite adsorbed $\mathrm{Zn}^{2+}$ of different concentrations $\left(25^{\circ} \mathrm{C}\right)$. 


\section{Conclusions}

(1) With a certain temperature, the higher the initial concentration of $\mathrm{Zn}$, the smaller the adsorption removal rate, and the higher the adsorption concentration. At the same concentration, the removal rate and adsorption concentration of $\mathrm{Zn}$ in mixed soil increased with the increase in temperature. The higher the initial concentration is, the more significant the influence of temperature on the adsorption capacity of $\mathrm{Zn}$ is.

(2) The adsorption of $\mathrm{Zn}$ by mixed soil is mainly an ion exchange process. The fitting results show that the adsorption of $\mathrm{Zn}$ by mixed soil conforms to the PSO dynamic adsorption model. According to the intra-particle diffusion model, the adsorption mode of $\mathrm{Zn}$ by mixed soil is controlled by both intra-particle diffusion and membrane diffusion.

(3) Thermodynamic analysis shows that the sum $\Delta H_{0}$ and $\Delta S_{0}$ of $\mathrm{Zn}$ adsorption by mixed soil is positive, indicating that the adsorption reaction is an endothermic process and the adsorption reaction is irreversible, and desorption does not occur easily; $\Delta G_{0}$ are negative, and decrease with the increase in temperature, indicating that the adsorption of $\mathrm{Zn}$ by mixed soil is a spontaneous process and the spontaneity increases with the increase in temperature.

(4) The zeta potential test results showed that the zeta potential value gradually increased with the increase in the initial concentration of $\mathrm{Zn}$ at $25^{\circ} \mathrm{C}, 40^{\circ} \mathrm{C}$ and $55^{\circ} \mathrm{C}$. When the concentration is constant, the zeta potential of the suspension system between the mixed soil and $\mathrm{Zn}$ increases with the increase in temperature, and the thickness of the double electric layer on the surface of the mixed soil decreases, which results in the weakening of the negative potential on the surface of the soil particles and affects the adsorption performance of the mixed soil. XRD and FTIR results show that the adsorption of $\mathrm{Zn}^{2+}$ by bentonite is interlayer and ion exchange occurs with the ions on the surface of bentonite.

Author Contributions: Conceptualization, S.X., Y.F., W.W. and Z.W.; validation, Y.F., W.W.; formal analysis, Y.F., W.W.; investigation, Y.F., W.W., C.L., M.B.; data curation, Y.F.; writing-original draft preparation, Y.F., W.W., S.X.; supervision, S.X., Z.W. All authors have read and agreed to the published version of the manuscript.

Funding: This project was supported by the Zhejiang Provincial Natural Science Foundation (LY20E080022).

Institutional Review Board Statement: This study did not require ethical approval.

Informed Consent Statement: Informed consent was obtained from all subjects involved in the study.

Data Availability Statement: Data sharing not applicable.

Conflicts of Interest: The authors declare no conflict of interest.

\section{References}

1. Chen, Y.-M. A fundamental theory of environmental geotechnics and its application. Chin. J. Geotech. Eng. 2014, $36,1-46$.

2. Xue, Q.; Liu, S.; Zhan, L.; Hu, L.; Du, Y. Environmental geotechnics: State-of-the-art of theory, testing and application to practice. China Civ. Eng. J. 2020, 53, 80-94.

3. Du, Y.J.; Jin, F.; Liu, S.Y.; Chen, L.; Zhang, F. Review of stabilization/solidification technique for remediation of heavy metals contaminated lands. Rock Soil Mech. 2011, 32, 116-124.

4. Chen, Y.-M.; Shi, J.-Y.; Zhu, W.; Zhan, L.-T. A review of geoenvironmental engineering. China Civ. Eng. J. 2012, 45, 165-182.

5. Zhang, W.J.; Wen-Qiang, J.I.A.; Zhang, G. Advection and dispersion of Cl-in clay-bentonite barriers. Chin. J. Geotech. Eng. 2013, 35, 2076-2081.

6. Fan, R.D.; Du, Y.J.; Chen, Z.B.; Liu, S.Y. Compressibility and permeability characteristics of lead contaminated soil-bentonite vertical cutoff wall backfills. Chin. J. Geotech. Eng. 2013, 35, 841-848.

7. Ministry of Housing and Urban-Rural Development. PRC.CJJ 176-2012 Technical Specification for Geotechnical Engineering of Sanitary Landfill site for Household Garbage; China Building Industry Press: Beijing, China, 2012.

8. Chen, Y.M.; Wang, Y.Z.; Xie, H.J.; Jiang, Y.S. Adsorption characteristics of loess-modified natural silt towards Pb(II): Equilibrium and kinetic tests. Chin. J. Geotech. Eng. 2014, 36, 1185-1194. 
9. Liu, R.; Du, Y.-J.; Mei, D.-B.; Jiang, N.-J.; Mei, Z.-H.; Feng, X.-W. Laboratory study of soil-bentonite vertical barrier on heavy mental migration retardation. J. Disaster Prev. Mitig. Eng. 2018, 38, 815-821.

10. Shi, M.-M.; Liu, M.-Y.; Zeng, Y.-L.; Su, S.-P.; Chen, Y.-X. Adsorption properties of heavy metal ions $\mathrm{Zn}^{2+}, \mathrm{Pb}^{2+}$ and Cd $\mathrm{Cd}^{2+}$ by diatomite and bentonite. Environ. Chem. 2012, 31, 162-167.

11. Wang, Y.-X.; Wang, H.; Lu, P. Adsorption and kinetics of heavy metal (Zn) over biochars in solution. Chem. Ind. Eng. Prog. 2019, $38,5142-5150$.

12. Doğan, M.; Türkyilmaz, A.; Alkan, M.; Demirbaş, Ö. Adsorption of copper(II) ions onto sepiolite and electrokinetic properties. Desalination 2009, 238, 257-270. [CrossRef]

13. Wang, Q.; Li, J.-S.; Poon, C.-S. Using incinerated sewage sludge ash as a high-performance adsorbent for lead removal from aqueous solutions: Performances and mechanisms. Chemosphere 2019, 226, 587-596. [CrossRef]

14. El-Enein, S.A.; Okbah, M.A.; Hussain, S.G.; Soliman, N.F.; Ghounam, H.H. Adsorption of Selected Metals Ions in Solution Using Nano-Bentonite Particles: Isotherms and Kinetics. Environ. Process. 2020, 34, 1-15. [CrossRef]

15. Guo, S.H.; Xu, Z.J.; Li, F.W.; Xu, D.D. Adsorption of Pb(II), Zn(II) from aqueous solution by biochars. Chin. J. Environ. Eng. 2015, 9, 3215-3222.

16. Chwastowski, J.; Bradło, D.; Żukowski, W. Adsorption of Cadmium, Manganese and Lead Ions from Aqueous Solutions Using Spent Coffee Grounds and Biochar Produced by Its Pyrolysis in the Fluidized Bed Reactor. Materials 2020, 13, 2782. [CrossRef]

17. Alandis, N.M.; Aldayel, O.A.; Mekhemer, W.K.; Hefne, J.A.; Jokhab, H.A. Thermodynamic and kinetic studies for the adsorption of $\mathrm{Fe}(\mathrm{III})$ and $\mathrm{Ni}(\mathrm{II})$ ions from aqueous solution using natural bentonite. J. Dispers. Sci. Technol. 2010, 31, 1526-1534. [CrossRef]

18. Somasundaran, P.; Fuerstenau, D.W. Mechanisms of alkyl sulfonate adsorption at the alumina-water interface1. J. Phys. Chem. 2002, 70, 90-96. [CrossRef]

19. Tang, X.; Li, Z.; Chen, Y. Behaviour and mechanism of Zn(II) adsorption on Chinese loess at dilute slurry concentrations. J. Chem. Technol. Biotechnol. 2008, 83, 673-682. [CrossRef]

20. Alkan, M.; Demirbas, O.; Dogan, M. Zeta potential of unexpanded and expanded perlite samples in various electrolyte media. Microporous Mesoporous Mater. 2005, 84, 192-200. [CrossRef]

21. Pehlivan, E.; Altun, T.; Cetin, S.; Bhanger, M.I. Lead sorption by waste biomass of hazelnut and almond shell. J. Hazard. Mater. 2009, 167, 1203-1208. [CrossRef]

22. Langmuir, I. The constitution and fundamental properties of solids and liquids: Part I. Solids. J. Am. Chem. Soc. 1916, 38, 2221-2295. [CrossRef]

23. Langmuir, I. The constitution and fundamental properties of solids and liquids. Part II. Liquids. Pergamon 1917, 184, 1848-1906. [CrossRef]

24. Freundlich, H. Over the adsorption in solution. J. Phys. Chem. 1906, 57, 1100-1107.

25. Dubinin, M.M.; Zaverina, E.D.; Radushkevich, L.V. Sorption and Structure of Active Carbons I. Adsorption of Organic Vapors. Zhurnal Fizicheskoi Khimii 1947, 21, 1351-1362.

26. Giles, C.H.; Smith, D.; Huison, A. A general treatment and classification of the solute sorption isotherms: I Theoretical. J. Colloid Interface Sci. 1974, 47, 755-765. [CrossRef]

27. Do, D.D. Adsorption Analysis: Equilibrium and Kinetics; Imperial College Press: London, UK, 1988.

28. Li, Z.-Z. Mechanism of Sorption, Desorption, Diffusion and Remediation of Heavy Metals in Soils; Zhejiang University: Hangzhou, China, 2009.

29. Zhu, J.; Wu, Q.D.; Wang, P.; Li, K.L.; Lei, M.J.; Zhang, W.L. Application of Classical Isothermal Adsorption Models in Heavy Metal Ions Diatomite System and Related Problems. Environ. Sci. 2013, 34, 4341-4348.

30. Lagergren, S. About the theory of so-called adsorption of soluble substances. Kungliga Svenska Vetenskapsakademiens Handlingar Band 1898, 24, 1-39.

31. Ho, Y.S. Review of second-order models for adsorption systems. J. Hazard. Mater. 2006, 136, 681-689. [CrossRef]

32. Aydin, S.; Kajjumba, G.W.; Emik, S.; Öngen, A.; Özcan, H.K. Modelling of Adsorption Kinetic Processes-Errors, Theory and Application. IntechOpen 2018, 1-19. Available online: https://cdn.intechopen.com/pdfs/63161.pdf (accessed on 10 March 2021). [CrossRef]

33. Li, A.-M.; Wu, H.-S.; Zhang, Q.-X. The preparation and immobilized on magnetic composite microspheres. Chem. Biodivers. 2004, $22,259-267$.

34. Meena, A.K.; Mishra, G.K.; Rai, P.K.; Rajagopal, C.; Nagar, P.N. Removal of heavy metal ions from aqueous solutions using carbon aerogel as an adsorbent. J. Hazard. Mater. 2005, 122, 161-170. [CrossRef] 